\section{Differentiating service quality impact between the online and off-line context: an empirical investigation of a corporate travel agency}

Differentiating service quality

\author{
Ling Fang
}

Information Technology Management, Ryerson University, Toronto, Canada Zhen $\mathrm{Lu}$

Ted Rogers School of Hospitality and Tourism Management, Ryerson University, Toronto, Canada, and

Linyin Dong

Information Technology Management, Ryerson University, Toronto, Canada 11 October 2020
Abstract

Purpose - Corporate travel represents a significant source of revenue for the tourism industry. Therefore, the quality of service is essential for maintaining and expanding corporate cliental bases. Despite the importance, the extant literature has yet sufficiently examined corporate travel service quality (SQ) and its impact. To make up for the drawback, this study aims to differentiate the impact of SQ perceptions on customer satisfaction between the online and off-line contexts through an empirical investigation in one of the top five corporate travel agencies in North America.

Design/methodology/approach - The well-established SERVQUAL measurement is applied in differentiating the impact of SQ dimensions between the online and off-line context. To empirically test the proposed corporate travel agency (CTA) SQ conceptual model, a set of survey data of "Welcome Back Survey" from HRG (a top five CTA in North America) was examined.

Findings - The study finds that for online services, assurance, responsiveness and empathy affect perceived $\mathrm{SQ}$, whereas for off-line services, assurance, empathy and tangible are the three dimensions of perceived SQ. Research limitations/implications - By relying on the existing survey, the off-line context has one less dimension than the online context. Yet as an early effort in differentiating the differences in the impact of SQ between two service contexts, the study offers insightful findings.

Practical implications - The findings will be helpful for business managers of CTAs to identify the factors that influence SQ in both online booking and off-line booking context. In particular, assurance and empathy are two dimensions that exert a significant impact on customer satisfaction.

Originality/value - This paper is the first to compare the differences of the SQ of online and off-line corporate travel.

Keywords Corporate travel agency (CTA), SERVQUAL, Service quality, HRG

Paper type Research paper

\section{Introduction}

Service quality (SQ) is of paramount importance in the service industry (Torres, 2014). Improved SQ will satisfy and even delight customers, thus reducing the churn rate and

(C) Ling Fang, Zhen Lu and Linyin Dong. Published in International Hospitality Review, Published by Emerald Publishing Limited. This article is published under the Creative Commons Attribution (CC BY 4.0) licence. Anyone may reproduce, distribute, translate and create derivative works of this article (for both commercial and non-commercial purposes), subject to full attribution to the original publication and authors. The full terms of this licence may be seen at http://creativecommons.org/licences/by/4.0/ legalcode

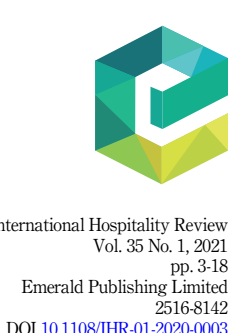

Received 13 January 2020 Revised 3 September 2020 Accepted 12 October 2020 
IHR

35,1

Figure 1.

Online, online-assisted and traditional reservation trend, year 2011-2015 securing stable revenues (Ciunova-Shuleska et al., 2013). In the tourism trade sector, corporate travel agency (CTA) plays important roles by providing services to corporate clients to meet their business travel needs, controlling travel expenses and providing travel solutions (Chircu et al., 2001; Morrison et al., 1994; Gustafson, 2012). Though business travel represents a significant market segment in tourism, many studies seem to emphasize SQ of the leisure travel agency sector (Martínez Caro and Martínez García, 2008; Ciunova-Shuleska et al., 2013; Kaynama and Black, 2000; Kim and Lee, 2004; Riel et al., 2004; Ryan and Cliff 1997; Tsang et al., 2010; Van Dyke et al., 1997).

Though online booking has seen its increased adoption versus traditional CTA off-line booking, business travelers still rely on the traditional booking services offered by "live" offline travel agents (National Business Travel Association (NBTA) (2010)). According to HRG, one of the top five global CTAs (Anonymous, 2014), traditional (offline) bookings stay around $70 \%$ and remain an intractable part in the process of making travel arrangements for the travelers. Figure 1 presents the percentage of off-line, online and online-assisted booking data. In spite of the rise of online travel booking services,

As shown in Figure 1, the online and off-line booking proportion trend indicates that the online and off-line contexts in the CTA sector will coexist for a long time to come.

Despite a plethora of studies on SQ, research comparing the impact of SQ in online and offline contexts is rare. In this study, we will investigate differences of the impact of SQ on the CTA booking services between both online and off-line contexts.

To do so, we adopt the well-established SQ measurement instrument SERVQUAL developed by Parasuraman et al. (1988). The construct measurement has been examined in both the online (Ho and Lee, 2007) and off-line contexts (Marinković et al., 2013), and thus considered relevant for the purpose of the study.

The purpose of this study is to explore which SQ dimension affects customer satisfaction in online and off-line travel services.

\section{Literature review}

\section{Service quality}

The concept of SQ has been widely studied and applied in various service industries, such as banking (Ali and Raza, 2017), healthcare (Al-Neyadi et al., 2018), airport luggage handler (Rezaei et al., 2018), hotels (e.g. Devi Juwaheer, 2004; Stefano et al., 2015) and travel agencies

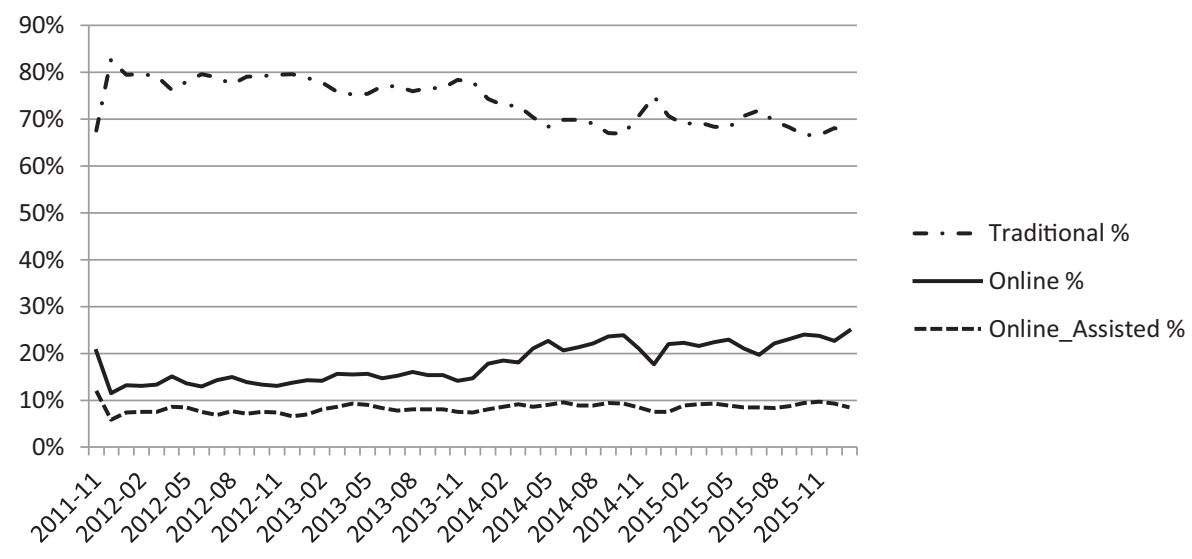

Source(s): HRG North America 
(Marinković et al., 2013). However, studies are lacking focusing on the CTA industry. SQ is defined as customer evaluation of the overall excellence of the service (Parasuraman et al., 1988) and overall perceived judgment (Grönroos, 1984). It is proposed as an antecedent of consumer satisfaction (Cronin and Taylor, 1992).

"Services" are different from the "Goods" mainly due to the three distinct characteristics: intangibility, heterogeneity and simultaneous production and consumption (inseparability) (Schneider and White, 2004; Xu et al., 2013). The intangibility of service denotes that by comparing with "tangible goods," services cannot be seen, touched and verified in advance of sales to assure quality (Parasuraman et al., 1985, 1988), because services encompass processes and performance rather than objects (Schneider and White, 2004). Unlike production of goods, services have no physical materialization (Schneider and White, 2004). This intangibility perspective results in the difficulty of understanding customers' perception and SQ evaluation (Ding and Keh, 2017). Heterogeneity means that different customers might have different expectations and experience, or that different service personnel might service the same customers differently (García-Quevedo et al., 2011). The same demands might be satisfied differently depending on the people involved. The heterogeneity nature of service makes it difficult to control SQ even though the firm has the service standard (Schneider and White, 2004). What services customers received may not be the same as what the firm intends to deliver (Parasuraman et al., 1985). Inseparability indicates that services occur during the service delivery from the service firm personnel to their customers. The production and consumption of services cannot be separated. Service firms cannot fully control over the SQ since the customer participation is intensely intertwined with service providers during service processing. Therefore, customers' experience is important to evaluate the quality of service performance (Moeller, 2010; Parasuraman et al., 1985).

\section{Service quality measurement}

The three distinct characteristics of service products contribute to the difficulty and complexity of measuring SQ. There have been plenty of studies devoted to developing models and scales to measure SQ. Parasuraman et al. (1985) in their seminal work on measuring SQ pointed out that "service quality is more difficult for the consumer to evaluate than goods quality. Service quality perceptions result from a comparison of consumer expectations with actual service performance" (p. 2). Fonseca (2009) argued that SQ equals customer satisfaction, which denotes customers' subjective perception regarding quality of services, and is driven from the customers' experience and their expectations. Schneider and White (2004) developed a user-based approach of SQ evaluation based on how SQ is subjectively defined on the personal experience of customers.

Grönroos (1984) developed the SQ model from technical and functional quality perspectives. While service technical quality is focused on how customers perceive services, service functional quality represents what service content influences the customers. Parasuraman et al. (1988), drawing on the three characteristics of services, intangibility, inseparability and heterogeneity, introduced the conceptual foundation of SQ with the five dimensions measuring instrument, which is termed SERVQUAL, indicating the five distinct dimensions: (p. 23):

(1) Tangible: Physical facilities, equipment and appearance of personnel

(2) Reliability: Ability to perform the promised service dependably and accurately

(3) Responsiveness: Willingness to help customers and provide prompt service

(4) Assurance: Knowledge and courtesy of employees and their ability to inspire trust and confidence

Differentiating service quality 
IHR

35,1
(5) Empathy: Caring, individualized attention the firm provides its customers

Parasuraman et al. (1988) further verified the reliability of SERVQUAL model with factor analysis, and assessed its validity through using one-way ANOVA (Parasuraman et al., 1988).

Since SERVQUAl was developed and introduced by Parasuraman et al. $(1988,1991)$, it has been successfully applied by many researchers in various industries (see Table 1 for the summary of the prior research by applying SERVQUAL). Referring to Parasuraman et al.'s measurements between expectations and perceptions, LeBlanc (1992) stated that customer's expectations would influence their perceptions of quality. His exploratory study in travel agencies was based on the data collected from customer's databases provided by two travel agencies. The questionnaire was designed in terms of the perception-expectation difference, which integrated Parasuraman et al.'s (1988) two sets of perception measurement and expectation measurement into one, focusing on the difference of perception-expectation. Kang et al. (2002) applied SERVQUAL to internal SQ and confirmed that it was an appropriate SQ measurement tool. Their confirmatory factor analysis revealed that the five dimensions of the SERVQUAL model - reliability, assurance, tangible, empathy and responsiveness - were distinct and conceptually clear. Marinković et al. (2013) explored travelers' satisfaction in the travel agency services. They tested each of the five dimensions of the SERVQUAL model on customer satisfaction and concluded that all dimensions (i.e. reliability, responsiveness, empathy and tangibility) except assurance had a significant influence on customer satisfaction. Xu et al. (2013) investigated the role of SQ in the e-service context and found that in the traditional off-line context format, SQ is a fundamental criterion of success for online companies (online activities). They further indicated that the five dimensions of the widely applied SQ model, SERVQUAL, were also supportive to measure SQ for the relatively new domain of online business (Xu et al., 2013). Online SERVQUAL was empirically tested by Kim and Lee (2004) and Kaynama and Black (2000). Van Dyke et al. (1997) indicated that the development of industry-specific measures of SQ should be taken into account when applying SERVQUAL model (Van Dyke et al., 1997).

\section{Service quality in corporate travel agency industry}

The management of corporate travel is fundamental in supporting businesses in any business field where a company needs to reach its clients and coworkers (Senkane, 2018). CTAs provide services to corporations whose business model is "Business to Business" (B2B). Since the services are usually contract-based, the relationship between CTAs and their clients is relatively stable (Gustafson, 2012). But the services are orientated in "Business to Customer" (B2C) because the services are provided between CTA counselors and corporate customers. The five dimensions of the SERVQUAL model can be an appropriate instrument to assess the quality of CTAs services.

The Global Business Travel Association (GBTA) explained that the CTA functions are to provide services for business travel needs in order to meet corporate goals and financial controls, facilitate adherence to corporate travel policies, realize savings through negotiated discounts, serve as a valuable information center and ensure travel efficiency (GBTA Foundation, 2014). For the contract-based business, high-level of SQ is the fundamental requirement. For instance, there is a distinct item "Service Level Agreement" (SLA) when HRG (one of the top global CTAs) signs a contract with a corporate client. The SLA also includes a survey to the clients to assess the SQ rendered by the CTA. The higher the SQ the travel agencies provide, the more competitive they are in the market. The travel agency industry is centered on the communication among agents, customers, technological service vendors and travel service vendors. The Internet has become the most important communication medium for CTAs to provide online services. By booking online, clients can access the collected information and implement travel policy directly. National Business 


\begin{tabular}{|c|c|c|c|c|}
\hline$\underline{\text { Study reference }}$ & Main topic & $\begin{array}{l}\text { Research } \\
\text { method }\end{array}$ & $\begin{array}{l}\text { Findings and SQ measurement } \\
\text { dimensions }\end{array}$ & $\begin{array}{l}\text { Differentiating } \\
\text { service quality }\end{array}$ \\
\hline Grönroos (1984) & $\begin{array}{l}\text { SQ Model and its } \\
\text { marketing implications }\end{array}$ & Survey & $\begin{array}{l}\text { SQ defined as expected service and } \\
\text { perceived service } \\
\text { Dimensions: technical quality, } \\
\text { functional quality }\end{array}$ & \\
\hline $\begin{array}{l}\text { Parasuraman et al. } \\
\text { (1985), Grobelna and } \\
\text { Marciszewska (2013) }\end{array}$ & $\begin{array}{l}\text { A conceptual model of } \\
\text { service quality and its } \\
\text { implications for future } \\
\text { research }\end{array}$ & $\begin{array}{l}\text { Focus group } \\
\text { interview }\end{array}$ & $\begin{array}{l}\text { Confirmed SQ is the comparison } \\
\text { between expectations and } \\
\text { performance } \\
\text { Dimensions: reliability, } \\
\text { responsiveness, competence, access, } \\
\text { courtesy, communication, credibility, } \\
\text { security, understanding, tangibles }\end{array}$ & 7 \\
\hline $\begin{array}{l}\text { Parasuraman et al. } \\
\text { (1988), Torres (2014) }\end{array}$ & $\begin{array}{l}\text { SERVQUAL: A multiple- } \\
\text { item scale for measuring } \\
\text { consumer perceptions of } \\
\text { service quality }\end{array}$ & Survey & $\begin{array}{l}\text { Based on the prior PZB } 1985 \text { research } \\
\text { of SQ } 10 \text { facets, } \\
\text { generated SERVQUAL and verified } \\
\text { the reliabilities and assessed the } \\
\text { validity } \\
\text { Dimensions: tangible, reliability, } \\
\text { responsiveness, assurance and } \\
\text { empathy }\end{array}$ & \\
\hline $\begin{array}{l}\text { Parasuraman et al. } \\
\text { (1991) }\end{array}$ & $\begin{array}{l}\text { Refinement and } \\
\text { reassessment of the } \\
\text { SERVQUAL scale }\end{array}$ & Survey & $\begin{array}{l}\text { Comparative discussing with other } \\
\text { SERVQUAL replication studies, } \\
\text { refined and reexamined its reliability } \\
\text { and validity; most valuable when it is } \\
\text { used periodically to track SQ trends } \\
\text { Dimensions: tangible, reliability, } \\
\text { responsiveness, assurance and } \\
\text { empathy }\end{array}$ & \\
\hline LeBlanc (1992) & $\begin{array}{l}\text { Evaluation of SQ in travel } \\
\text { management companies }\end{array}$ & $\begin{array}{l}\text { Personal } \\
\text { interview } \\
\text { and survey }\end{array}$ & $\begin{array}{l}\text { Referring to PZB both measurements } \\
\text { between expectations and } \\
\text { perceptions, LeBlanc (1992) stated } \\
\text { perceptions of quality are influenced } \\
\text { by expectations. His exploratory } \\
\text { study in travel agencies is based on } \\
\text { that data collected directly in terms of } \\
\text { the perception-expectation difference } \\
\text { on a Likert-type scale } \\
\text { Dimensions: tangible, reliability, } \\
\text { responsiveness, assurance and } \\
\text { empathy }\end{array}$ & \\
\hline Pitt et al. (1995) & $\begin{array}{l}\text { SQ effectiveness } \\
\text { measurement }\end{array}$ & & $\begin{array}{l}\text { Demonstrated that SERVQUAL is } \\
\text { applicable in the information systems } \\
\text { arena } \\
\text { Dimensions: tangible, reliability, } \\
\text { responsiveness, assurance and } \\
\text { empathy } \\
\text { (continued) }\end{array}$ & $\begin{array}{r}\text { Table 1. } \\
\text { Prior research on } \\
\text { service quality }\end{array}$ \\
\hline
\end{tabular}


IHR

35,1

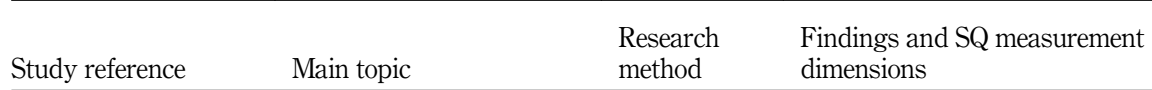

Kang et al. (2002) Measurement of internal Survey Confirmed SERVQUAL is a useful

SQ tool for the measurement of SQ, with

the majority of the research to date

8

Ho and Lee (2007)

Marinkovic et al. 2011

Xu et al., (2013) e-travel service quality

scale

Impact of SERVQUAL in Survey travel management companies

Integrating $\mathrm{SQ}$ with system and information quality

Survey
Dimensions: tangible, reliability, responsiveness, assurance and empathy

Developed a five-factor scale for evaluating online travel service quality on the basis of SERVQUAL SERVQUAL dimensions are important antecedents that trigger satisfaction

Dimensions: tangible, reliability, responsiveness, assurance and empathy

Discussed 25 SERVQUAL

utilizations and indicated that SERVQUAL is also widely support to measure $\mathrm{SQ}$ for the online business Dimensions: tangible, reliability, responsiveness, assurance and empathy

Table 1.

Travel Association (NBTA) (2010) reports showed 93\% of US domestic or simple routing flights were booked online. For most international flights and complex trips, business travelers still rely on travel agents services. Therefore, the coexistence of online and off-line services provided by CTAs warrants the examination of the impact of each service on customer satisfaction.

\section{Modeling and measuring service quality and customer satisfaction \\ Measuring customer satisfaction}

Prior studies demonstrated that a high SQ level resulted from a high level of customer satisfaction (Cronin et al., 2000; Brady and Robertson, 2001; Yang et al., 2009). Zeithaml et al. (1996) also showed evidences that customers' perception of SQ triggers their satisfaction. Based on a study in the travel industry, Marinković et al. (2013) suggested setting a relationship between each individual SERVQUAL component and customer satisfaction. Applying these researchers' suggestions into the research model, this study will build the linkages among the variables shown in Figure 2 and investigate how important each variable contributes to the satisfaction.

Parasuraman et al. $(1985,1988)$ developed SERVQUAL - the five dimensions model determining $\mathrm{SQ}$, in which perceived tangible, reliability, responsiveness, assurance and empathy measure customer satisfactions. The hypotheses can be made that SQ is positively and reciprocally related to customer satisfaction (Riel et al., 2004). Based on the SQ SERVQUAL studies discussed above, a research model for measuring SQ of a CTA is derived and shown in Figure 2. There are six latent variables: tangibility, reliability, responsiveness, assurance, empathy and satisfaction. Satisfaction as a dependent variable was added by Parasuraman et al. $(1985,1988)$ to SERVQUAL model in order to test the empirical relations among the five latent variables. Taking into consideration the functions of a CTA, this model will be applied in both the online context and off-line context in this study. 


\section{Hypotheses}

This study will apply Parasuraman et al.'s (1988) five dimensions of the SERVQUAL model in the CTA SQ measurement with an added dependent variable, satisfaction, as shown in Figure 3.

\section{Online context}

Reliability (OnREL). In online booking context, reliability is the IT system's ability to find the most applicable information. Corporates control travel expenses through corporate travel policies in order to "maximize travel safety and efficiency through the 'best' fare" (Guizzardi et al., 2017, p. 129). A CTA serves as a valuable information center by providing information about fares at a negotiated discount on different types of flights, hotels and car rentals that could meet customer preferences. It can, therefore, be expected that:

H1. _OnREL: In the online services model, the reliability of a CTA services to find the most applicable fare is positively related to overall quality perceptions.

Tangible (OnTANG). In the online context, the dimension of tangible is reflected as "accessibility," "navigation" and "design and presentation" (Ho and Lee, 2007; Kaynama and Black, 2000). A CTA needs to ensure its services adhere to corporate travel policies and meet corporate financial goals. As corporate travel clients' profiles are usually executed by IT
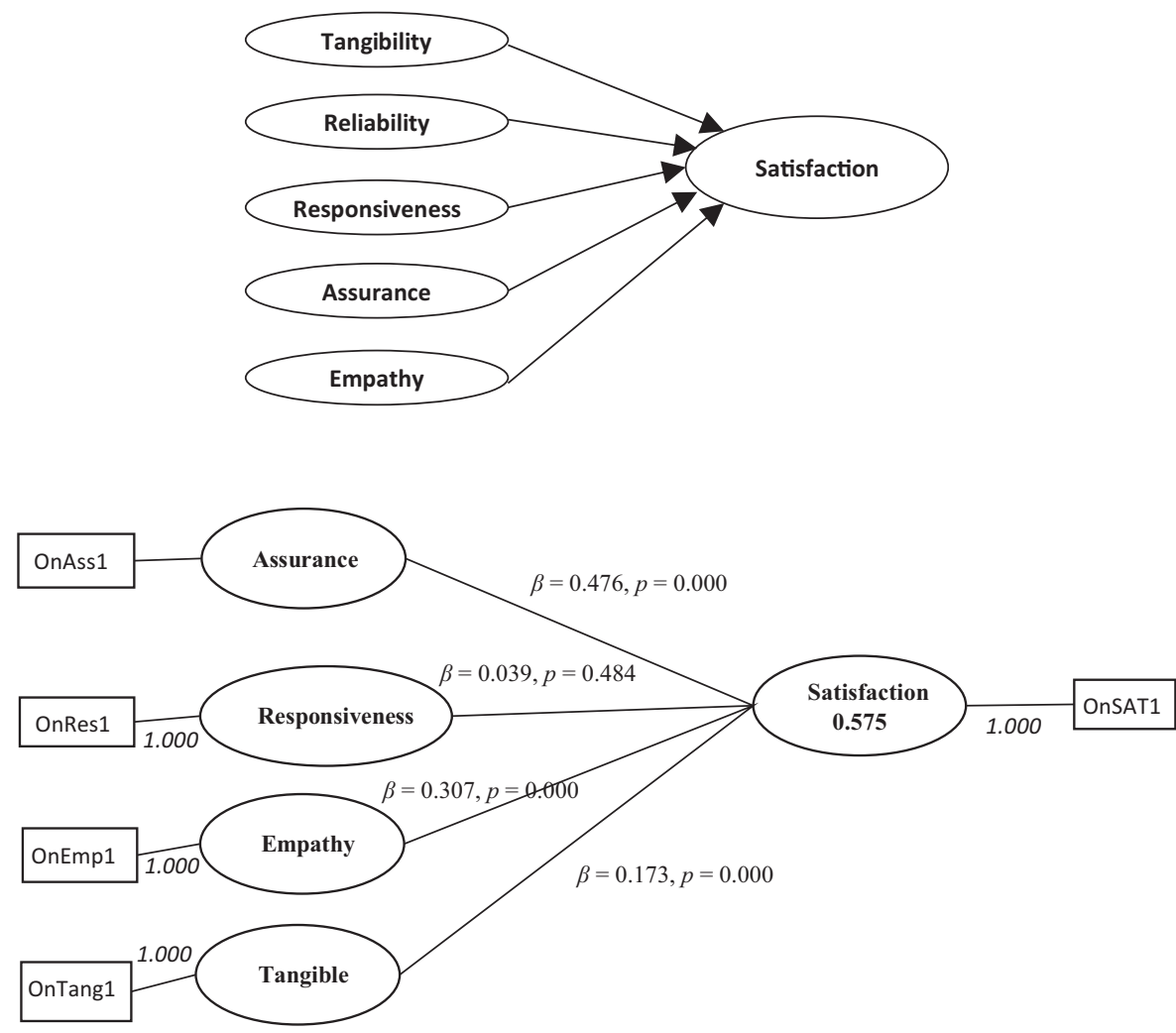

Differentiating service quality

Figure 2. CTA service quality measurement model
Figure 3.

PLS off-line structural model and hypotheses test 
IHR

35,1

systems, the ease of accessing and updating client profiles is a crucial element for clients to evaluate services. Therefore, this leads to the following hypothesis:

H2. _OnTANG: In the online services format, the tangibility of CTA services is positively related to overall quality perceptions.

Empathy (OnEMP). The CTA functions require the services to serve as a valuable information source. For instance, it is necessary for customers to be able to access the help channel to get the assistance services. It can, therefore, be posited that:

H3. _OnEMP: In the online services model, the empathy of CTA services is positively related to overall quality perceptions.

Responsiveness (OnRES). Responsiveness reflects the timeliness of ticket and itinerary delivery. In many CTAs, the service such the itinerary delivery is associated with the service fee charge level. The faster and more accurately a provider responds to requests, the better the service will be evaluated. Therefore, it is hypothesized that:

H4. _OnRES: In the online services model, perceived responsiveness of CTA services is positively related to the customers' satisfaction.

Assurance (OnASSU) The assurance is the aspect of services to provide sufficient information to inspire trust and confidence for customers. The CTA functions require the services to serve as a valuable information center and facilitate adherence to corporate travel policies. In the corporate services sector, security and privacy are usually guaranteed by a secure log-in process (e.g. HTTPS web site, VeriSign). Therefore, it is hypothesized that:

H5. _OnASSU: In the online services model, perceived assurance of CTA services is positively related to overall customer satisfaction.

\section{Off-line context}

Tangible (OffTANG). "Tangibles are the 'visible' aspects of the service that are employed by businesses to improve external customer satisfaction" (Panda and Das, 2014, p. 53). In off-line context, the CTA functions require travel agents to provide excellent personal services to facilitate corporate travel booking adherence to corporate travel policies and to meet corporate goals. It is therefore hypothesized that:

H6. _OffTANG: In the off-line services model, service providers need to meet the company's travel policies and choose the preferred supplier and fares for the customers; therefore the tangibility of a CTA provided is positively related to overall quality perceptions.

Empathy (OffEMP). The CTA functions require the services to serve as a valuable information source. For instance, it is necessary for customers to be able to access the help channel to get the assistance services. That service agent counselors care and pay individualized attention to customers definitely impacts customer's perceived satisfaction. The following hypothesis is thus proposed:

H7. _OffEMP: In the off-line services model, empathy of a CTA providing the accessibility to counselors has positive influence on overall quality perceptions.

Responsiveness (OffRES). In the off-line booking context, responsiveness denotes the time that a CTA takes to respond to clients' inquiries and requests related to tickets and itinerary delivery. The CTA functions require the services to ensure travel efficiency and meet corporate goals. Therefore, it is expected that: 
H8. _OffRES: In the off-line services model, the timeliness of delivery of the services is positively related to overall quality perceptions.

Assurance (OffASSU). The CTA functions require the services to serve as an accurate information center and facilitate adherence to corporate travel policies. Therefore, it is expected that:

H9. _OffASSU: In the off-line services model, providing accuracy services positively lead to overall quality perceptions.

\section{Methodology}

To test the proposed CTA SQ conceptual model, the data from the "Welcome Back Survey" conducted by HRG (one of the top five corporate travel agencies in North America) were used. The "Welcome Back Survey" is a required component of the company's travel services contract completed by each client when making travel reservations through travel agents either online or off-line. The data from two mega clients $\mathrm{ABC} 1$ and $\mathrm{ABC} 2$ over two years 2014 and 2015 were used for the model testing. Table 2 shows the indicators used in the questionnaire design for online and off-line survey.

A total of 25,592 survey questionnaires were sent, and 1,315 were responded (see Table 3), resulting in $5 \%$ of the response rate. Among the returned responses, 858 were off-line with 843 being valid, 457 were online with 437 being valid. The online and off-line surveys contained eight and five questions, respectively. Both surveys had a customer satisfaction question in which clients were asked to indicate the level of agreement with statements about their personal perceptions of SQ on the 10-point Likert scale, where $0=$ strongly unsatisfied to $10=$ strongly satisfy.

To test the conceptual model, we employed partial least square (PLS), a component-based structural equation modeling for reasons. First, it offers a simultaneous analysis of the measurement model as well as the structural model (for construct relationships), which provides accurate estimates of the paths among constructs (Barclay et al., 1995; Chin 1998a,

\begin{tabular}{|c|c|c|}
\hline & Indicator & Statement \\
\hline \multicolumn{3}{|l|}{ Online } \\
\hline \multirow[t]{2}{*}{ Tangible } & OnTang1 & Ease in completing and updating your personal profile \\
\hline & OnTang2 & $\begin{array}{l}\text { The system's ability to display information about your company policy and } \\
\text { preferred suppliers }\end{array}$ \\
\hline Reliability & OnRel1 & The system's ability to find the most applicable fare \\
\hline Responsiveness & OnRes1 & The timeliness of your ticket and itinerary delivery \\
\hline \multirow[t]{2}{*}{ Assurance } & OnAss1 & The display and choice of flights \\
\hline & OnAss2 & The search, display and selection of hotel properties \\
\hline Empathy & OnEmp1 & $\begin{array}{l}\text { The service provided by our central fulfilment service if you have had occasion } \\
\text { to request assistance on booking or technical issues }\end{array}$ \\
\hline Satisfaction & OnSat1 & Your overall experience with HRG \\
\hline \multicolumn{3}{|l|}{ Off-line } \\
\hline Tangible & OffTang1 & $\begin{array}{l}\text { Your counselor's effort to provide you with the lowest logical airfare in } \\
\text { keeping with your company policy }\end{array}$ \\
\hline Responsiveness & OffRes1 & The timeliness of your ticket and itinerary delivery \\
\hline Assurance & OffAss1 & The accuracy of your reservation \\
\hline Empathy & OffEmp1 & The accessibility of your counselor team \\
\hline
\end{tabular}

Source(s): HRG 2014 and 2015

Table 2. Indicators in the questionnaires 
IHR

35,1

\section{2}

Table 3.

Survey response

1998b). Second, it is a particularly valuable statistical method for exploratory studies (Hair et al., 2014). An application of SmartPLS 3.0 is adopted for this statistical analysis.

\section{Data analysis}

\section{Off-line measurement model}

The measurement model was assessed by checking construct validity (including convergent validity and discriminant validity) as well as reliability. The convergent validity was assessed by (1) checking whether factors of corresponding constructs exhibited loadings above 0.70 (Chen, 2010), and (2) verifying whether average variance extracted (AVE) score for each construct was above 0.50 (Fornell and Larcker 1981; Chen 2010).

In off-line measurement, the factor loading for each construct was 1 , as only one indicator was used for each construct.

Discriminant validity was evaluated by checking whether each factor loading was higher under its corresponding construct than under any other construct, and whether the square root of AVE for each construct was larger than its correlation with other constructs (Chen 2010; Chin, 1998b). A close examination of factor cross-loadings (see Table 4), construct correlations and AVEs revealed strong discriminant validity. We assessed reliability based on composite reliability, which uses actual item loadings to calculate the internal consistency reliability (Werts et al., 1974). All constructs had the composite reliability above 0.80, demonstrating strong reliability.

The complete model for the off-line context explained $57.5 \%$ of variance of satisfaction (see Figure 3) and 53.9\% for the online context (see Figure 4). Hypotheses test results were shown in Table 4.

As shown in Figure 3, assurance significantly influenced customer satisfaction $(\beta=0.476$, $p<0.001)$. Similarly, both empathy $(\beta=0.307, p=0.000)$ and tangibility $(\beta=0.0 .173$, $p=0.000$ ) significantly affect perceived satisfaction. The off-line model explained $57.5 \%$ of the variance in satisfaction. However, responsiveness was not a significant antecedent of customer satisfaction $(\beta=0.039, p=0.484)$.

\begin{tabular}{|c|c|c|c|c|c|}
\hline Client & Year & Survey sent & Online type response & Off-line type response & Total responses \\
\hline & 2014 & 7,384 & 26 & 285 & 311 \\
\hline \multirow{2}{*}{$\mathrm{ABC} 1$} & 2015 & 5,471 & 252 & 245 & 497 \\
\hline & 2014 & 629 & 3 & 23 & 26 \\
\hline \multirow[t]{2}{*}{$\mathrm{ABC} 2$} & 2015 & 12,108 & 176 & 305 & 481 \\
\hline & & Total & Online 457 & Off-line 858 & \\
\hline
\end{tabular}

Table 4.

Online discriminant validity

\begin{tabular}{lcccccc}
\hline & Assurance & Empathy & Reliability & Responsiveness & Satisfaction & Tangible \\
\hline OnAss1 & 0.901 & 0.320 & 0.597 & 0.386 & 0.671 & 0.450 \\
OnAss2 & 0.810 & 0.341 & 0.624 & 0.358 & 0.497 & 0.61 \\
OnEmp1 & 0.382 & 1.000 & 0.398 & 0.469 & 0.430 & 0.462 \\
OnRel1 & 0.706 & 0.398 & 1.000 & 0.473 & 0.541 & 0.642 \\
OnRes1 & 0.434 & 0.469 & 0.473 & 1.000 & 0.507 & 0.513 \\
OnSAT1 & 0.693 & 0.430 & 0.541 & 0.507 & 1.000 & 0.524 \\
OnTang1 & 0.522 & 0.384 & 0.531 & 0.436 & 0.450 & 0.913 \\
OnTang2 & 0.586 & 0.464 & 0.649 & 0.507 & 0.514 & 0.934 \\
\hline
\end{tabular}




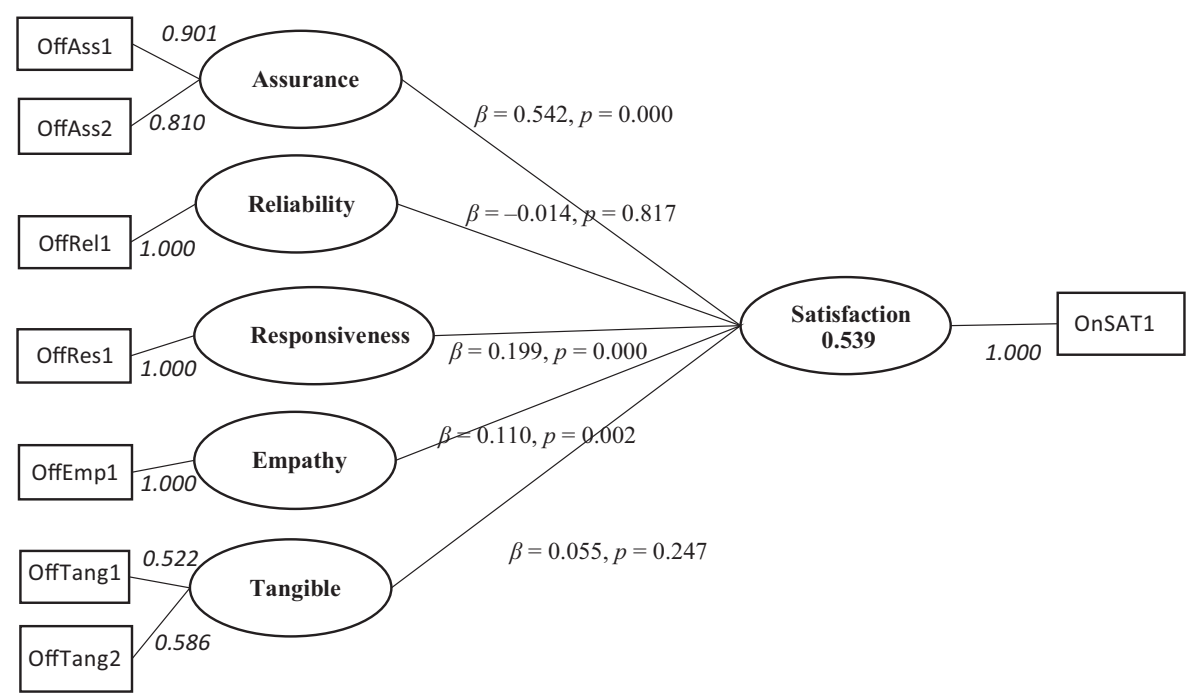

Differentiating service quality

Online measurement model

As assurance and tangibility contained two measurement items, validity and reliability of these two constructs were evaluated. The SmartPLS analysis indicated that AVEs for both constructs were higher than 0.5 and construct loadings higher than 0.7 , which indicated acceptable convergent and discriminant validity (Chen, 2010). The online model explained $53.9 \%$ of the variance (see Table 5 ).

The beta value confirmed that assurance was the best predictor of customer satisfaction $(\beta=0.542, p=0.000)$, followed by responsiveness $(\beta=0.199, p=0.000)$ and empathy $(\beta=0.110, p=0.002)$. However, tangible $(\beta=0.055, p=0.247)$ and reliability $(\beta=0.014$, $p=0.817$ ) appeared not to be statistically significant in influencing customers' satisfaction (Tsang et al., 2010).

The summary of the hypotheses testing is reported in Table 6 .

\section{Discussions}

The results of the PLS analysis indicate that relative contributions of the SERVQUAL dimensions to customer satisfaction differ between the online context and the off-line context. In particular, this study has identified assurance, empathy and tangible as three SQ dimensions that bear a significant influence on customer satisfaction in the off-line context, which is in line with Marinkovic et al.'s finding on the dimensions of SERVQUAL on

\begin{tabular}{|c|c|c|c|c|c|c|}
\hline & $\begin{array}{c}\text { Original } \\
\text { sample (O) }\end{array}$ & $\begin{array}{l}\text { Sample } \\
\text { mean (M) }\end{array}$ & $\begin{array}{l}\text { Standard error } \\
\text { (STRERR) }\end{array}$ & $\begin{array}{c}T \text { statistics } \\
(|\mathrm{O} / \mathrm{STERR}|)\end{array}$ & $\begin{array}{c}p \\
\text { values }\end{array}$ & \\
\hline Assurance $>$ Satisfaction & 0.542 & 0.543 & 0.070 & 7.767 & 0.000 & \\
\hline Empathy $>$ Satisfaction & 0.110 & 0.112 & 0.036 & 3.045 & 0.002 & \\
\hline Reliability $>$ Satisfaction & -0.014 & -0.016 & 0.061 & 0.231 & 0.817 & Table 5. \\
\hline Responsiveness $>$ Satisfaction & 0.199 & 0.194 & 0.043 & 4.589 & 0.000 & Online path \\
\hline Tangible $>$ Satisfaction & 0.055 & 0.056 & 0.047 & 1.160 & 0.247 & coefficients \\
\hline
\end{tabular}


IHR

35,1

traditional travel agency (2011). For online services, three significant SQ dimensions are assurance, responsiveness and empathy.

Assurance is the aspect of services to provide sufficient information to inspire trust and confidence in customers by travel agents in the off-line traditional service format. This dimension is found to be the most important aspect of SQ in the off-line format and online format, which is consistent with Tsang and colleagues' study (2010), who reported that website functionality, information content and quality are the most important dimensions of e-service quality in travel agencies. The finding implies that in both the off-line and online context, knowledge and expertise of corporate travel counselors are crucial in contributing to customer satisfaction (Martínez Caro and Martínez García, 2008).

Responsiveness in the online context refers to effective handling of the timeliness of clients' fares and itinerary delivery via the Internet. In the online context, CTA's prompt service to customers via the Internet can make customers feel more satisfied with the purchasing, and thus to continue purchasing (Li et al., 2009).

Empathy in both the online and off-line context is found to positively impact customer satisfaction. Empathy was measured by the customers' response to the accessibility of counselors. This significant impact of empathy is also found in other studies (Riel et al., 2004; Marinkovic et al. (2013); Kang et al., 2002) and is in line with the understanding that empathy is fundamental to customer satisfaction (Marinković et al., 2013). Caring and individualized attention affect customers satisfaction in CTAs in online and off-line contexts (Holma et al., 2015). By comparing online and off-line booking, this study explains that a CTA's SQ should focus on assurance and empathy in both contexts. The results confirm that the SERVQUAL measurements are applicable in both online and off-line service contexts.

Tangible is one of the important contributing factors to customer satisfaction in the offline context. In the off-line context, the CTA should focus around the modern equipment, attractiveness of the interior design of the office and well-trained professional business counselors (Marinković et al., 2013).

SERVQUAL is a tested useful instrument for measuring the quality of service in various service industries, although there is some criticism of its shortcomings (e.g. Cronin and Taylor, 1994). SERVQUAL is illustrated in this research as a valid tool for evaluating both online and off-line CTA SQ.

\section{Recommendations and managerial implications}

Today, business managers as well as academics recognize the importance of SQ in driving consumers' satisfaction and future purchase decisions (Chircu et al., 2001; Torres, 2014). The results of this study will be useful for the business managers of CTAs to identify the factors that influence SQ regardless of the context under which services are offered. Our data analysis indicates that both assurance and empathy are significant predictors of customer satisfaction in both the online and off-line contexts. This finding highlights the importance of caring, individualized attention, protection of individual privacy and securing business

Table 6.

Hypotheses - impact on customer satisfaction

\begin{tabular}{llll}
\hline & \multicolumn{3}{c}{ Hypotheses - impact on customer satisfaction } \\
& This study in CTA & Prior research in the leisure services sector \\
& Online & Off-line & Marinkovic et al. (2013) \\
\hline Assurance & Supported & Supported & Not supported \\
Reliability & Not supported & Not tested & Supported \\
Responsiveness & Supported & Not supported & Supported \\
Empathy & Supported & Supported & Supported \\
Tangible & Not supported & Supported & Supported
\end{tabular}


transactions in maintaining and improving customer satisfaction. The CTA industry managers are, therefore, advised to continue cultivating a strong culture promoting clientcentered services and dedicating resources to ensure service counselors to be equipped with necessary knowledge and skills to provide quality services.

\section{Limitations and future research}

There have been very few studies that investigate SQ in both contexts in one industry sector. This empirical study was driven from the needs of real business world by pulling data from a CTA's industry service operations and processes. The data of the survey of customers responding to the questionnaire designed to measure the SQ of a CTA over two years' span make this study unique. The two distinct service process models of online booking and offline booking within one service organization shed light for other CTAs to improve their SQ. However, as data of this study were from a secondary data source, the pre-design questionnaire limits number of indicators that could be used to measure each dimension of SERVQUAL.

For future research, first-hand data collection is needed to overcome the limits of this explorative study in measuring each dimension of SERVQUAL subject to using a secondary data source. In addition, the dimensions of the SERVQUAL for measuring online and off-line CTA services should be modified in order to better reflect the nature of the two different business formats of CTAs.

\section{Conclusions}

The quality of service is essential for maintaining and expanding corporate cliental bases. The research findings reveal that in the off-line context, assurance, empathy and tangible are significant antecedents to customer satisfaction. This finding highlights the importance of caring and individualized attention, protection of individual privacy and securing business transactions in increasing customer satisfaction, cultivating a strong culture of promoting client-centered services and dedicating resources to ensure service counselors are equipped with necessary knowledge and skills to provide quality services.

In the online context, the research findings reveal that assurance, responsiveness and empathy significantly contribute to customer satisfaction. Therefore, business managers in CTAs should focus on effective handling of the timeliness of clients' fares, itinerary deliver and company's prompt service to customers via the Internet and designing a robust technical online system to increase competitive advantages.

\section{References}

Ali, M. and Raza, S.A. (2017), "Service quality perception and customer satisfaction in Islamic banks of Pakistan: the modified SERVQUAL model", Total Quality Management and Business Excellence, Vol. 28 Nos 5-6, pp. 559-577, doi: 10.1080/14783363.2015.1100517.

Al-Neyadi, H.S., Abdallah, S. and Malik, M. (2018), "Measuring patient's satisfaction of healthcare services in the UAE hospitals: using SERVQUAL", International Journal of Healthcare Management, Vol. 11 No. 2, pp. 96-105, doi: 10.1080/20479700.2016.1266804.

Anonymous (2014), "Most CT100 buyers hike spending”, Business Travel News, Vol. 31 No. 14, pp. 3-4.

Barclay, D., Higgins, C. and Thompson, R. (1995), "The partial least square (PLS) approach to causal modeling: personal computer adoption and use as an illustration”, Technology Studies, Vol. 2 No. 2, pp. 285-309.

Brady, M.K. and Robertson, C.J. (2001), "Searching for a consensus on the antecedent role of service quality and satisfaction: an exploratory cross-national study", Journal of Business Research, Vol. 51 No. 1, pp. 53-60. 
IHR

35,1

Chen, H.J. (2010), “Linking employees' e-learning system use to their overall job outcomes: an empirical study based on the IS success model”, Computers and Education, Vol. 55 No. 4, pp. 1628-1639, doi: 10.1016/j.compedu.2010.07.005.

Chin, W.W. (1998a), "Issues and opinion on structural equation modeling", MIS Quarterly, Vol. 22 No. 1, pp. vii-xvi.

Chin, W.W. (1998b), "The partial least squares approach to structural equation modeling", in Marcoulides, G.A. (Ed.), Modern Methods for Business, Lawrence Erlbaum Associates, New Jersay, pp. 295-336.

Chircu, A., Kauffman, R. and Keskey, D. (2001), "Maximizing the value of internet-based corporate travel reservation systems", Communications of the ACM, Vol. 44 No. 11, pp. 57-63.

Ciunova-Shuleska, A., Palamidovska, N. and Grishin, M. (2013), "An empirical assessment of service quality in the context of travel agencies in the Republic of Macedonia”, Tržište/Market, pp. 21-36.

Cronin, J.J. and Taylor, S.A. (1992), "Measuring service quality: a reexamination and extension", Journal of Marketing, Vol. 56 No. 3, p. 55, doi: 10.2307/1252296.

Cronin, J.J., Brady, M.K. and Hult, G.T.M. (2000), “Assessing the effects of quality, value, and customer satisfaction on consumer behavioral intentions in service environments", Journal of Retailing, Vol. 76 No. 2, pp. 193-218, doi: 10.1016/S0022-4359(00)00028-2.

Devi Juwaheer, T. (2004), "Exploring international tourists' perceptions of hotel operations by using a modified SERVQUAL approach - a case study of Mauritius", Managing Service Quality: An International Journal, Vol. 14 No. 5, pp. 350-364, doi: 10.1108/09604520410557967.

Ding, Y. and Keh, H.T. (2017), "Consumer reliance on intangible versus tangible attributes in service evaluation: the role of construal level", Journal of the Academy of Marketing Science, Vol. 45 No. 6, pp. 848-865, doi: 10.1007/s11747-017-0527-8.

Fonseca, J.R. (2009), “Customer satisfaction study via a latent segment model”, Journal of Retailing and Consumer Services, Vol. 16 No. 5, pp. 352-359.

Fornell, C. and Larcker, D.F. (1981), "Evaluating structural equation models with unobservable variables and measurement error", Journal of Marketing Research, Vol. 18, pp. 39-50.

García-Quevedo, J., Mas-Verdú, F. and Soriano, D.R. (2011), "The heterogeneity of services and the differential effects on business and territorial innovation", International Journal of Technology Management, Vol. 54 No. 1, pp. 80-93, doi: 10.1504/IJTM.2011.038830.

GBTA Foundation (2014), GBTA BTI Outlook - Annual Global Report \& Forecast, GBTA Foundation, Alexandria.

Grobelna, A. and Marciszewska, B. (2013), "Measurement of service quality in the hotel sector: the case of Northern Poland", Journal of Hospitality Marketing and Management, Vol. 22 No. 3, pp. 313-332, doi: 10.1080/19368623.2013.753816.

Grönroos, C. (1984), “A service quality model and its marketing implications”, European Journal of Marketing, Vol. 18 No. 4, pp. 36-44, doi: 10.1108/EUM0000000004784.

Guizzardi, A., Stacchini, A. and Ranieri, E. (2017), "Best buy: what does it mean in corporate travel?”, Current Issues in Tourism, Vol. 20 No. 2, pp. 129-134, doi: 10.1080/13683500.2015.1133571.

Gustafson, P. (2012), "Managing business travel: developments and dilemmas in corporate travel management", Tourism Management, Vol. 33 No. 2, pp. 276-284, doi: 10.1016/j.tourman.2011. 03.006 .

Hair, J.J., Sarstedt, M., Hopkins, L. and Kuppelwieser, V.G. (2014), "Partial least squares structural equation modeling (PLS-SEM) an emerging tool in business research", European Business Review, Vol. 26 No. 2, pp. 106-121.

Ho, C.I. and Lee, Y.L. (2007), "The development of an e-travel service quality scale", Tourism Management, Vol. 28 No. 6, pp. 1434-1449, doi: 10.1016/j.tourman.2006.12.002. 
Holma, A.M., Bask, A. and Kauppi, K. (2015), "Ensuring corporate travel compliance - control vs. commitment strategies”, Tourism Management, Vol. 51, pp. 60-74, doi: 10.1016/j.tourman.2015. 04.008 .

Kang, G., Jame, J. and Alexandris, K. (2002), "Measurement of internal service quality:application of the SERVQUAL battery to internal service quality", Managing Service Quality, Vol. 12 No. 5, pp. 278-91.

Kaynama, S.A. and Black, C.I. (2000), "A proposal to assess the service quality of online travel agencies: an exploratory study", Journal of Professional Services Marketing, Vol. 21 No. 1, pp. 63-88.

Kim, W.G. and Lee, H.Y. (2004), "Comparison of web service quality between online travel agencies and online travel suppliers", Journal of Travel and Tourism Marketing, Vol. 17 Nos 2-3, pp. 105-116.

LeBlanc, G. (1992), "Factors affecting customer evaluation of service quality in travel agencies: an investigation of customer perceptions", Journal of Travel Research, Vol. 32 Spring, pp. 10-16.

Li, H., Liu, Y. and Suomi, R. (2009), "Measurement of eservice quality: an empirical study on online travel service", 17th European Conference on Information Systems, ECIS 2009.

Marinković, V., Senić, V., Kocić, M. and Šapić, S. (2013), "Investigating the impact of SERVQUAL dimensions on customer satisfaction: the lessons learnt from Serbian travel agencies", International Journal of Tourism Research, Vol. 15, pp. 184-196, doi: 10.1002/jtr.

Martínez Caro, L. and Martínez García, J.A. (2008), "Developing a multidimensional and hierarchical service quality model for the travel agency industry", Tourism Management, Vol. 29 No. 4, pp. 706-720, doi: 10.1016/j.tourman.2007.07.014.

Moeller, S. (2010), "Characteristics of services - a new approach uncovers their value", Journal of Services Marketing, Vol. 24 No. 5, pp. 359-368, doi: 10.1108/08876041011060468.

Morrison, A.M., Ladig, K.A. and Hsieh, S. (1994), "Corporate travel in the USA. Characteristics of managers and departments", Tourism Management, Vol. 15 No. 3, pp. 177-184, doi: 10.1016/ 0261-5177(94)90102-3.

National Business Travel Association (NBTA) (2010), Corporate Travel Policy: Benchmarking and Insight, Global Business Travel Association, Alexandria.

Panda, T.K. and Das, S. (2014), "The role of tangibility in service quality and its impact on external customer satisfaction: a comparative study of hospital and hospitality sectors", The IUP Journal of Marketing Management, Vol. 13 No. 4, pp. 53-69.

Parasuraman, A., Zeithaml, V.A. and Berry, L.L. (1985), “A conceptual model of service quality and its implications for future research", Journal of Marketing, Vol. 49 Fall, pp. 41-50.

Parasuraman, A., Zeithaml, V.A. and Berry, L.L. (1988), "SERVQUAL: a multiple-item scale for measuring consumer perceptions of service quality", Journal of Retailing, Vol. 64 Spring, pp. $12-40$.

Parasuraman, A., Berry, L.L. and Zeithaml, V.A. (1991), "Refinement and reassessment of the SERVQUAL scale", Journal of Retailing, Vol. 67 No. 4, pp. 420-450.

Pitt, L.F., Watson, R.T. and Kavan, C.B. (1995), "Service quality: a measure of information systems effectiveness”, MIS Quarterly, Vol. 19 No. 2, pp. 173-187.

Rezaei, J., Kothadiya, O., Tavasszy, L. and Kroesen, M. (2018), "Quality assessment of airline baggage handling systems using SERVQUAL and BWM", Tourism Management, Vol. 66, pp. 85-93, doi: 10.1016/j.tourman.2017.11.009.

Riel, A.C., Semeijn, J. and Pauwels, P. (2004), "Online travel service quality: the role of pre-transaction services”, Total Quality Management, Vol. 15 No. 4, pp. 475-493.

Ryan, C. and Cliff, A. (1997), "Do travel agencies measure up to customer expectation? An empriical envestigation of travel agencies' service quality as measured by SERVQUAL", Journal of Travel and Tourism Marketing, Vol. 6 No. 2, pp. 1-31. 
IHR

35,1

Schneider, B. and White, S.S. (2004), Service Quality Research Perspectives, Sage Publications, London.

Senkane, L. (2018), "Development of corporate travel management system`s content for Company X", available at: https://www.theseus.fi/bitstream/handle/10024/152101/Senkane_Matisane.Liga. pdf?sequence $=1$.

Stefano, N.M., Casarotto Filho, N., Barichello, R. and Sohn, A.P. (2015), "A fuzzy SERVQUAL based method for evaluated of service quality in the hotel industry", Procedia CIRP, Vol. 30, pp. 433-438, doi: 10.1016/j.procir.2015.02.140.

Torres, E.N. (2014), "Deconstructing service quality and customer satisfaction: challenges and directions for future research", Journal of Hospitality Marketing and Management, Vol. 23 No. 6, pp. 652-677, doi: 10.1080/19368623.2014.846839.

Tsang, N.K., Lai, M.T. and Law, R. (2010), "Measuring e-service quality for online travel agencies", Journal of Travel and Tourism Marketing, Vol. 27 No. 3, pp. 306-323.

Van Dyke, T.P., Kappelman, L.A. and Prybutok, V.R. (1997), "Measuring information systems service quality: concerns on the use of the SERVQUAL questionnaire", MIS Quarterly: Management Information Systems, Vol. 21 No. 2, pp. 195-207, doi: 10.2307/249419.

Werts, C.E., Linn, R.L. and Joreskog, K.G. (1974), "Intraclass reliability estimates: testing structural assumptions", Educational and Psychological, Vol. 34, pp. 25-33.

$\mathrm{Xu}$, J., Benbasat, I. and Cenfetelli, R.T. (2013), "Integrating service quality with system and information quality: an empirical test in the E-service context", MIS Quarterly, pp. 777-794.

Yang, H.-E., Wu, C.-C. and Wang, K.-C. (2009), "An empirical analysis of online game service satisfaction and loyalty", Expert Systems with Applications, Vol. 36 No. 2, pp. 1816-1825.

Zeithaml, V.A., Berry, L.L. and Parasuraman, A. (1996), "The behavioral consequences of service quality”, Journal of Marketing, Vol. 60 April, pp. 31-46.

\section{Corresponding author}

Zhen Lu can be contacted at: zhenlu@ryerson.ca

For instructions on how to order reprints of this article, please visit our website:

www.emeraldgrouppublishing.com/licensing/reprints.htm

Or contact us for further details: permissions@emeraldinsight.com 